\title{
Efficiency evaluation of resourcing innovative processes on a regional level
}

\author{
Maria Rakhova $^{1}$, Maria Zakirova ${ }^{1}$, and Sergey Grachev ${ }^{1, *}$ \\ ${ }^{1}$ Vladimir State University named after Alexander and Nikolay Stoletovs, 600005, Gorkogo str, 79, \\ Vladimir, Russia
}

\begin{abstract}
The purpose of this issue is to analyse how efficient the resource providing innovation processes in Russian regions is. This issue gives a hypothesis that says: the assessment of innovation activity's full efficiency should be carried out only if three criteria are met: effectiveness, productivity and optimality. An analysis of innovation processes was conducted in the context of regions of the Central Federal District (CFD) for the period of 2010-2017. In most regions, there was a decrease in the estimated parameter over the mentioned period of time. These trends are caused by the decrease in the amount of technological innovation costs with an optimal ratio of the volume ratio of innovative goods made, work and services. The research results can be useful for federal and regional executive authorities. They can formulate and adjust the planned strategy of socio-economic development and calculate the cumulative efficiency indicator of innovation processes.
\end{abstract}

\section{Introduction}

In conditions of limited economic resources and artificially developed restrictions of their inflow as a result of foreign sanctions, regions should concentrate their efforts on increasing the efficiency of using resource potential that is already available. At the same time, it is necessary to take into account universal development trends in which the use of innovative technologies and methods of managing their significant high-quality growth and acceleration of economic development is possible.

The concept of efficiency is ambiguous, and a large number of definitions of this category is currently being created. Each definition differs in directions of scientific thought, in whose favor it is considered.

In a more general sense, efficiency is understood as a definition of a ratio of received results and made expenses. It should be noted that, in our opinion, this definition is very simplified. Because efficiency a has rather large number of definitions, it is possible to speak about their versatility and complexity. Any economic action has to be effective as a result of the efforts made, and as long as the economic entity receives this result, i.e. an effect is the carried-out efficiency and arises periodically, caused by the process course, in

\footnotetext{
${ }^{*}$ Corresponding author: grachev-sa@yandex.ru
} 
direct dependence on the logic of forwarding development, but not from the logic creation $[2]$.

It is worth noticing that quite a significant amount of researchers [3-6] so far is specified in their works on fundamental differences and allocate several approaches to the analysis of efficiency. Let's consider some definitions formulated in various directions of a scientific thought.

Some authors interpret efficiency as an indicator of striving for the final result, not the result itself, but a variant of correctness, accuracy of direction to get the final result [7-9]. In turn, this concept is based on the idea of P. Drucker, a classic of economic thought [10], who by efficiency understood "correctness" of product creation, while spending a minimum amount of all types of resources. This definition implies a qualitative approach. However, P. Drucker, along with efficiency, also singled out the concept of "effectiveness", by which he understood "to do the right things", in other words, goods (services) that are in great demand on the market.

The effectiveness of innovation should be interpreted as the most optimal combination of processes in the composition of operations carried out with the lowest resource costs in the framework of the general economic strategy of state development. Productivity as criteria for the correctness of the motion vector should be defined as the relevance of the results of activities in the stochastic conditions of the national socio-economic system.

It should be noted that the period of time to develop national economy can be characterized as the period of formation of the elements of the sixth technological paradigm. It is characterized by the increasing importance of the social component and the creation of a knowledge society. One of the factors that must be considered in this case are the interests of future generations, which is a simplified representation of the concept of sustainable development [11]. Accordingly, any activity, including innovation, should take into account the importance of this social vector of development of the economy and society as a whole [12-14].

Thus, the concept of complex efficiency requires to introduce social utility criteria. Without this it is not entirely correct to judge the optimality of the implementation of any type of activity. It is proposed to evaluate this concept through the term «optimality of innovation activity", which is defined as the degree of social utility that manifests itself in an increase of the level and quality of life of a population in a certain period while reducing the negative burden on future generations.

In this regard, it is necessary to judge the full effectiveness of innovation activity only in case of fulfillment of all three mentioned above criteria: effectiveness, productivity and optimality.

Innovation activity involves the connection of physical capital embodied in the form of real capital and intellectual capital, inseparable from the company's employees, as well as the institutional environment. The result of this interaction, as a rule, is an intellectual product formalized as an intangible asset, which is a structured as knowledge suitable for practical use.

If it's needed to be estimated in terms of non-material assets then it should be possible to draw a number of conclusions:

- it is possible to evaluate the effectiveness of innovation activity by the means of its profitability indicator, i.e. the ratio of investment and the final result of the total volume of innovative products produced;

- the productivity of innovative activity becomes possible to estimate through a ratio of quantity of the made intellectual products about the efforts made, which are formalized in the form of labor costs. The general tendency of economic subjects is to implement innovative activity; 
- the optimality of innovation activity can be analyzed by calculating the parameters of the environmental load, as well as the general level of financial well-being of the population.

\section{Methodology}

The assessment should be based on the statement that each of the selected aspects is equally important, which indicates the need to maximize them, thus condition (1) should be satisfied:

$$
\begin{aligned}
& C=R+E+O \\
& \left\{\begin{array}{l}
R \rightarrow \max \\
E \rightarrow \max \\
O \rightarrow \max
\end{array}\right.
\end{aligned}
$$

where $R$ - productivity of innovative activity;

$E$ - effectiveness of innovation activity;

$O$ - optimality of innovation activity.

Based on the logic of this issue, it seems appropriate to carry out a practical assessment of the cumulative efficiency $(\mathrm{C})$ of innovation through the following indicators:

- the productivity (results) of innovative activity (R):

1. The indicator $R_{1}$ defines quality of innovative activity and defined as a ratio of the sum of the developed advanced production technologies $\left(Q_{P T}\right)$ and the submitted patent applications for inventions $\left(Q_{P A}\right)$ to the number of staff occupied with research and development $(N p)$ :

$$
\mathrm{R}_{1}=\left(Q_{P T}+Q_{P A}\right) / N p
$$

2. The indicator $R_{2}$ characterizes extent of participation of the organization in implementation of innovative activity in general. It is defined as the ratio of the number of the organizations, which were carrying out technological, organizational or marketing innovations $\left(Q_{I O}\right)$, to total number of the organizations $\left(Q_{O}\right)$ surveyed for a certain period of time in the country, the industry, the region:

$$
\mathrm{R}_{2}=Q_{I O} / Q_{P A}
$$

- the effectiveness of innovation activity $(E)$ :

1. The indicator $E_{1}$ estimating the ratio of the volume of produced innovative goods, works, services $\left(\mathrm{V}_{\mathrm{IG}}\right)$ to the volume of costs for technological innovations $\left(\mathrm{C}_{\mathrm{TI}}\right)$ is calculated using the formula (4):

$$
\mathrm{E}_{1}=V_{I G} / C_{T I}
$$

2. The indicator $E_{2}$ is determined as the share of produced innovative goods, works, services in the total volume of manufactured products.

- the optimality of innovation activity $(O)$ :

1. The indicator $\mathrm{O}_{1}$ determines the ratio of pollutant emissions to the atmosphere, coming from stationary sources $(\mathrm{Z})$ to the population $(\mathrm{N})$ :

$$
O_{1}=Z / N
$$

2. The indicator $\mathrm{O}_{2}$ determines the level of financial well-being by estimating the ratio of 
the average monetary income of the population per capita $(\mathrm{P})$ and gross regional product per capita (GRP):

$$
\mathrm{O}_{2}=\mathrm{P} / \mathrm{GRP}
$$

In order to simplify the ranking of regions, the obtained data was normalized using formula 7 , followed by calculating the average value of the obtained indicators for each group using the geometric average formula.

$$
X_{\text {norm }}=X_{i} / X_{\max }
$$

where $X_{\text {norm }}$ - normalized indicator value;

$X_{i}$ - actual value of the indicator;

$X_{\max }$ - minimum and maximum value of the indicator for the group, respectively.

The analysis of innovative processes was conducted in the context of central federal district regions (CFD) for the period 2010-2017.

For example, normalized data $R_{l}$ is given in table 1 .

Table 1. Normalized indicators value $R_{l}$.

\begin{tabular}{|c|c|c|c|c|c|c|c|c|}
\hline & $\mathbf{2 0 1 0}$ & $\mathbf{2 0 1 1}$ & $\mathbf{2 0 1 2}$ & $\mathbf{2 0 1 3}$ & $\mathbf{2 0 1 4}$ & $\mathbf{2 0 1 5}$ & $\mathbf{2 0 1 6}$ & $\mathbf{2 0 1 7}$ \\
\hline Belgorod region & 0.122 & 0.110 & 0.121 & 0.225 & 0.440 & 0.200 & 0.151 & 0.102 \\
\hline Bryansk region & 0.082 & 0.054 & 0.081 & 0.154 & 0.217 & 0.155 & 0.178 & 0.101 \\
\hline Vladimir region & 0.044 & 0.030 & 0.052 & 0.072 & 0.146 & 0.093 & 0.055 & 0.038 \\
\hline Voronezh region & 0.049 & 0.047 & 0.066 & 0.098 & 0.174 & 0.126 & 0.074 & 0.038 \\
\hline Ivanovo region & 1.000 & 1.000 & 1.000 & 1.000 & 1.000 & 1.000 & 1.000 & 1.000 \\
\hline Kaluga region & 0.016 & 0.013 & 0.017 & 0.030 & 0.029 & 0.028 & 0.026 & 0.024 \\
\hline Kostroma region & 0.422 & 0.283 & 0.501 & 0.397 & 0.948 & 0.611 & 0.379 & 0.330 \\
\hline Kursk region & 0.084 & 0.060 & 0.075 & 0.148 & 0.237 & 0.155 & 0.153 & 0.073 \\
\hline Lipetsk region & 0.285 & 0.230 & 0.230 & 0.377 & 0.660 & 0.242 & 0.116 & 0.090 \\
\hline Moscow region & 0.019 & 0.015 & 0.032 & 0.041 & 0.054 & 0.035 & 0.035 & 0.032 \\
\hline Oryol region & 0.236 & 0.169 & 0.138 & 0.321 & 0.376 & 0.105 & 0.096 & 0.059 \\
\hline $\begin{array}{c}\text { Ryazan region } \\
\text { Kank region }\end{array}$ & 0.073 & 0.051 & 0.047 & 0.095 & 0.147 & 0.087 & 0.091 & 0.054 \\
\hline Smolensk & 0.079 & 0.094 & 0.137 & 0.255 & 0.175 & 0.080 & 0.053 \\
\hline $\begin{array}{c}\text { Tambov region } \\
\text { Tver region }\end{array}$ & 0.057 & 0.048 & 0.071 & 0.106 & 0.166 & 0.089 & 0.125 & 0.050 \\
\hline $\begin{array}{c}\text { Tula region } \\
\text { Yaroslavl region }\end{array}$ & 0.032 & 0.017 & 0.029 & 0.057 & 0.096 & 0.067 & 0.042 & 0.034 \\
\hline Moscow city & 0.050 & 0.030 & 0.042 & 0.070 & 0.091 & 0.104 & 0.050 & 0.022 \\
\hline
\end{tabular}

The calculation data results for criteria R, E, O are presented in table 2. 
Table 2. Calculated values of criteria R, E, O, regions of the Central Federal District, 2010-2017.

\begin{tabular}{|c|c|c|c|c|c|c|c|c|}
\hline \multicolumn{9}{|c|}{$\boldsymbol{R}$} \\
\hline & 2010 & 2011 & 2012 & 2013 & 2014 & 2015 & 2016 & 2017 \\
\hline Belgorod region & 0.316 & 0.268 & 0.244 & 0.343 & 0.519 & 0.356 & 0.333 & 0.285 \\
\hline Bryansk region & 0.233 & 0.167 & 0.196 & 0.256 & 0.308 & 0.244 & 0.251 & 0.184 \\
\hline Vladimir region & 0.178 & 0.133 & 0.190 & 0.205 & 0.312 & 0.228 & 0.172 & 0.135 \\
\hline Voronezh region & 0.179 & 0.153 & 0.178 & 0.232 & 0.309 & 0.263 & 0.211 & 0.156 \\
\hline Ivanovo region & 0.660 & 0.524 & 0.676 & 0.678 & 0.579 & 0.469 & 0.408 & 0.476 \\
\hline Kaluga region & 0.101 & 0.075 & 0.099 & 0.133 & 0.123 & 0.124 & 0.108 & 0.109 \\
\hline Kostroma region & 0.519 & 0.372 & 0.402 & 0.390 & 0.550 & 0.500 & 0.412 & 0.223 \\
\hline Kursk region & 0.211 & 0.210 & 0.228 & 0.295 & 0.353 & 0.238 & 0.227 & 0.140 \\
\hline Lipetsk region & 0.437 & 0.352 & 0.417 & 0.601 & 0.808 & 0.491 & 0.340 & 0.300 \\
\hline Moscow region & 0.097 & 0.082 & 0.121 & 0.137 & 0.159 & 0.118 & 0.124 & 0.124 \\
\hline Oryol region & 0.451 & 0.312 & 0.274 & 0.384 & 0.410 & 0.224 & 0.192 & 0.147 \\
\hline Ryazan region & 0.197 & 0.151 & 0.166 & 0.243 & 0.320 & 0.236 & 0.241 & 0.188 \\
\hline Smolensk region & 0.213 & 0.167 & 0.184 & 0.223 & 0.299 & 0.253 & 0.170 & 0.136 \\
\hline Tambov region & 0.188 & 0.123 & 0.180 & 0.226 & 0.283 & 0.207 & 0.262 & 0.173 \\
\hline Tver region & 0.095 & 0.083 & 0.120 & 0.169 & 0.203 & 0.163 & 0.131 & 0.126 \\
\hline Tula region & 0.182 & 0.169 & 0.180 & 0.275 & 0.305 & 0.239 & 0.185 & 0.123 \\
\hline Yaroslavl region & 0.155 & 0.138 & 0.161 & 0.200 & 0.228 & 0.144 & 0.121 & 0.102 \\
\hline Moscow city & 0.223 & 0.174 & 0.206 & 0.265 & 0.302 & 0.320 & 0.204 & 0.130 \\
\hline \multicolumn{9}{|c|}{$E$} \\
\hline Belgorod region & 0.254 & 0.512 & 0.514 & 0.530 & 0.522 & 0.454 & 0.312 & 0.358 \\
\hline Bryansk region & 0.426 & 0.499 & 0.483 & 0.243 & 0.691 & 0.982 & 0.989 & 0.398 \\
\hline Vladimir region & 0.190 & 0.610 & 0.603 & 0.410 & 0.594 & 0.295 & 0.297 & 0.344 \\
\hline Voronezh region & 0.492 & 0.328 & 0.262 & 0.167 & 0.539 & 0.459 & 0.316 & 0.196 \\
\hline Ivanovo region & 0.168 & 0.303 & 0.043 & 0.046 & 0.187 & 0.155 & 0.026 & 0.021 \\
\hline Kaluga region & 0.175 & 0.289 & 0.255 & 0.112 & 0.174 & 0.117 & 0.140 & 0.105 \\
\hline Kostroma region & 0.258 & 0.492 & 0.273 & 0.171 & 0.337 & 0.088 & 0.507 & 0.821 \\
\hline Kursk region & 0.100 & 0.248 & 0.190 & 0.128 & 0.459 & 0.554 & 0.636 & 0.568 \\
\hline Lipetsk region & 0.307 & 0.325 & 0.446 & 0.501 & 0.911 & 0.525 & 0.460 & 0.316 \\
\hline Moscow region & 0.699 & 0.732 & 0.425 & 0.356 & 0.595 & 0.317 & 0.463 & 0.329 \\
\hline Oryol region & 0.906 & 0.811 & 0.120 & 0.112 & 0.119 & 0.075 & 0.037 & 0.058 \\
\hline Ryazan region & 0.210 & 0.251 & 0.108 & 0.088 & 0.155 & 0.128 & 0.285 & 0.251 \\
\hline Smolensk region & 0.181 & 0.134 & 0.142 & 0.195 & 0.624 & 0.138 & 0.106 & 0.165 \\
\hline Tambov region & 0.265 & 0.400 & 0.164 & 0.121 & 0.432 & 0.207 & 0.163 & 0.214 \\
\hline Tver region & 0.843 & 0.691 & 0.412 & 0.280 & 0.170 & 0.268 & 0.201 & 0.075 \\
\hline Tula region & 0.208 & 1,000 & 0.661 & 0.349 & 0.669 & 0.478 & 0.453 & 0.408 \\
\hline Yaroslavl region & 0.433 & 0.437 & 0.413 & 0.235 & 0.441 & 0.191 & 0.774 & 0.506 \\
\hline Moscow city & 0.224 & 0.191 & 0.430 & 0.516 & 0.614 & 0.507 & 0.459 & 0.105 \\
\hline \multicolumn{9}{|c|}{$\boldsymbol{O}$} \\
\hline Belgorod region & 0.393 & 0.387 & 0.384 & 0.370 & 0.361 & 0.363 & 0.349 & 0.349 \\
\hline Bryansk region & 0.296 & 0.315 & 0.302 & 0.309 & 0.287 & 0.307 & 0.304 & 0.330 \\
\hline Vladimir region & 0.235 & 0.241 & 0.225 & 0.234 & 0.221 & 0.230 & 0.227 & 0.242 \\
\hline Voronezh region & 0.291 & 0.270 & 0.271 & 0.277 & 0.246 & 0.264 & 0.262 & 0.253 \\
\hline Ivanovo region & 0.321 & 0.336 & 0.308 & 0.310 & 0.334 & 0.336 & 0.309 & 0.283 \\
\hline Kaluga region & 0.164 & 0.171 & 0.162 & 0.182 & 0.191 & 0.241 & 0.217 & 0.225 \\
\hline Kostroma region & 0.449 & 0.435 & 0.418 & 0.420 & 0.403 & 0.420 & 0.447 & 0.455 \\
\hline Kursk region & 0.292 & 0.302 & 0.294 & 0.285 & 0.265 & 0.254 & 0.271 & 0.273 \\
\hline Lipetsk region & 0.804 & 0.781 & 0.798 & 0.826 & 0.725 & 0.743 & 0.719 & 0.717 \\
\hline Moscow region & 0.262 & 0.260 & 0.260 & 0.266 & 0.250 & 0.267 & 0.276 & 0.259 \\
\hline Oryol region & 0.279 & 0.281 & 0.188 & 0.273 & 0.205 & 0.198 & 0.247 & 0.243 \\
\hline Ryazan region & 0.534 & 0.505 & 0.489 & 0.452 & 0.450 & 0.448 & 0.439 & 0.418 \\
\hline Smolensk region & 0.352 & 0.358 & 0.340 & 0.382 & 0.352 & 0.395 & 0.381 & 0.386 \\
\hline Tambov region & 0.346 & 0.357 & 0.352 & 0.356 & 0.298 & 0.349 & 0.354 & 0.353 \\
\hline Tver region & 0.323 & 0.345 & 0.336 & 0.328 & 0.336 & 0.342 & 0.335 & 0.359 \\
\hline Tula region & 0.545 & 0.595 & 0.585 & 0.552 & 0.505 & 0.474 & 0.449 & 0.404 \\
\hline Yaroslavl region & 0.367 & 0.357 & 0.348 & 0.365 & 0.367 & 0.392 & 0.369 & 0.335 \\
\hline Moscow city & 0.095 & 0.093 & 0.095 & 0.092 & 0.085 & 0.087 & 0.083 & 0.081 \\
\hline
\end{tabular}


In order to simplify the obtained preliminary results evaluation in dynamics, the construction of scatterplots in coordinates "effectiveness-optimality-productivity" (Fig. 1) for the periods 2010 and 2017 was performed.

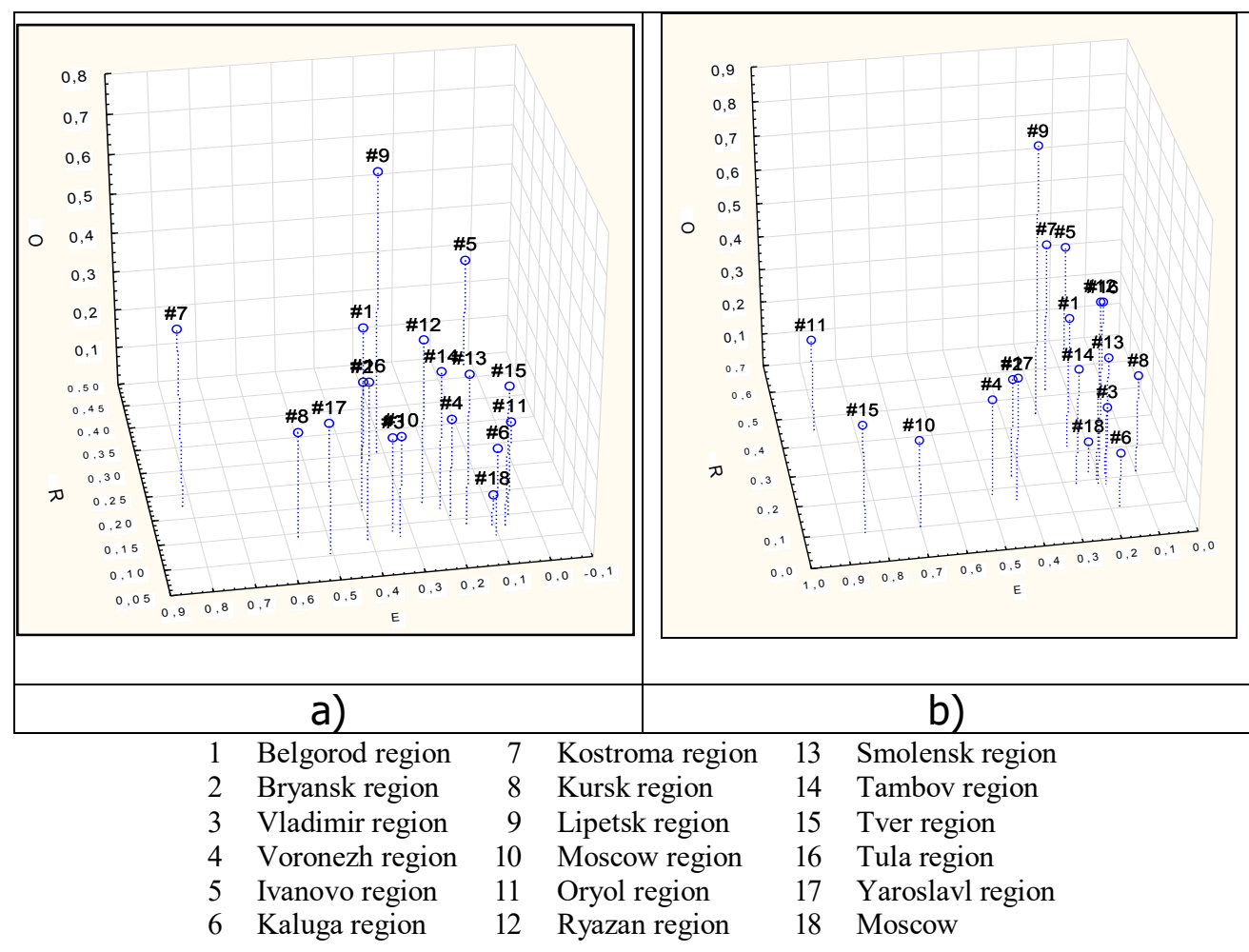

Fig. 1. Scatterplots in coordinates "effectiveness-optimality-productivity" for CFD a) 2010, b) 2017

According to the data presented in Fig.1, it becomes possible to conclude that there is a decrease in the differentiation of the subjects of the Central Federal District. In 2010 it was possible to identify several sets of territories:

- Oryol, Tver, Moscow regions;

- other regions of the Central Federal District.

By 2017, the rates of innovative development are leveled, which leads to the fact that only one region stands out from the total population - the Kostroma region, in which there is a lag in indicators $\mathrm{R}$ and $\mathrm{O}$ with the optimal value of criteria $\mathrm{E}$. This fact indicates an imbalance in the processes.

\section{Results}

According to the results of the study, an indicator was calculated for the cumulative efficiency of innovation processes in the context of the CFD territories in accordance with the formula (1). 
Table 2. Values of the indicator of the cumulative efficiency of innovation activities of the regions of the Central Federal District, 2010-2017.

\begin{tabular}{|c|c|c|c|c|c|c|c|c|}
\hline & $\mathbf{2 0 1 0}$ & $\mathbf{2 0 1 1}$ & $\mathbf{2 0 1 2}$ & $\mathbf{2 0 1 3}$ & $\mathbf{2 0 1 4}$ & $\mathbf{2 0 1 5}$ & $\mathbf{2 0 1 6}$ & $\mathbf{2 0 1 7}$ \\
\hline Belgorod region & 0.962 & 1.167 & 1.142 & 1.244 & 1.402 & 1.173 & 0.995 & 0.993 \\
\hline Bryansk region & 0.954 & 0.980 & 0.982 & 0.808 & 1.286 & 1.534 & 1.544 & 0.911 \\
\hline Vladimir region & 0.603 & 0.983 & 1.018 & 0.850 & 1.128 & 0.753 & 0.696 & 0.721 \\
\hline Voronezh region & 0.961 & 0.751 & 0.711 & 0.676 & 1.094 & 0.987 & 0.788 & 0.604 \\
\hline Ivanovo region & 1.149 & 1.163 & 1.027 & 1.033 & 1.100 & 0.960 & 0.743 & 0.780 \\
\hline Kaluga region & 0.440 & 0.536 & 0.516 & 0.427 & 0.488 & 0.482 & 0.465 & 0.439 \\
\hline Kostroma region & 1.226 & 1.299 & 1.093 & 0.981 & 1.290 & 1.008 & 1.366 & 1.499 \\
\hline Kursk region & 0.603 & 0.759 & 0.713 & 0.707 & 1.077 & 1.046 & 1.134 & 0.981 \\
\hline Lipetsk region & 1.549 & 1.458 & 1.661 & 1.928 & 2,444 & 1.759 & 1.520 & 1.334 \\
\hline Moscow region & 1.059 & 1.074 & 0.806 & 0.758 & 1.004 & 0.702 & 0.864 & 0.712 \\
\hline Oryol region & 1.637 & 1.403 & 0.581 & 0.768 & 0.734 & 0.497 & 0.476 & 0.449 \\
\hline Ryazan region & 0.941 & 0.907 & 0.763 & 0.784 & 0.925 & 0.812 & 0.965 & 0.857 \\
\hline Smolensk region & 0.746 & 0.659 & 0.667 & 0.800 & 1.275 & 0.785 & 0.657 & 0.687 \\
\hline Tambov region & 0.800 & 0.879 & 0.696 & 0.703 & 1.013 & 0.763 & 0.779 & 0.740 \\
\hline Tver region & 1.261 & 1.119 & 0.868 & 0.776 & 0.709 & 0.772 & 0.667 & 0.560 \\
\hline Tula region & 0.935 & 1.764 & 1.427 & 1.175 & 1.480 & 1.190 & 1.087 & 0.935 \\
\hline Yaroslavl region & 0.955 & 0.931 & 0.922 & 0.799 & 1.036 & 0.726 & 1.264 & 0.943 \\
\hline Moscow city & 0.542 & 0.459 & 0.732 & 0.873 & 1.001 & 0.914 & 0.746 & 0.316 \\
\hline
\end{tabular}

Note that in most regions, there was a decrease in the estimated parameter for the period under study. The exceptions were the Belgorod region (growth 3.2\%), the Vladimir region (growth 19.5\%), the Kostroma region (growth 22.2\%), the Kursk region (62.7\%), the Tula region (no change). The remaining territories demonstrate a decrease in the estimated criteria of varying intensity: the largest decrease occurred in the Oryol region (by $72.6 \%$ ) and the Tver region (by 55.6\%). These trends have influenced the composition of the group of leading territories: in 2010 they were Kostroma, Lipetsk, Orlov, and Tver regions; in 2017 - Kostroma and Lipetsk regions.

It should be emphasized that, usually, a decrease in the cumulative parameter is associated with a decrease in the criterion E (effectiveness), in particular with a negative change in the indicator $\mathrm{E}_{1}$.

\section{Conclusion}

Summarizing the research, it should be noted that questions of the innovation processes efficiency are very relevant in the highlight of economic policy. Given that the issue of innovation development is very closely related to the problems of ensuring sustainable development, the parameters of this direction should be included in the indicator of cumulative efficiency of innovation processes. The analysis revealed that for the period 2010-2017, there was a decrease in differentiation of territories of the Central Federal District. However, most regions are characterized by a decrease of the analyzed criteria with a simultaneous change in the composition of the leading subjects. These negative tendencies are caused, as a rule, by a decrease in optimality of the ratio of the volume of innovative goods produced, work, services to the volume of expenditures in technological innovations. 


\section{References}

1. M. Borza, Proc. Econ. A. Fin., 15, $1355-1363$ (2014):

2. https://doi: 10.1016/S2212-5671(14)00599-1

3. Mottaeva, IOP Conf. Series: Earth and Environmental Science, 90, 012120 (2017)

4. doi : $10.1088 / 1755-1315 / 90 / 1 / 012120$

5. N. G. Tzeremes Econ. Lett., 124, 127-131 (2014) https://doi.org/10.1016/j.econlet.2014.05.006

6. V. Bartošová, P. Majercák, D. Hrašková, Proc. Econ. \& Fin., 24, 68-75 (2015) doi: 10.1016/S2212-5671(15)00614-0

7. Martz V. A. J. O. Eval. 34, 385-401 (2013)

8. B. S. Georgopoulos, A. S. Tannenbaum, Am. Soc. Rev., 22(5), 534-540 (1957)

9. F. Phillips, J. Chang, Y.-Sh. Suet Jou. O. Innov. \& Kn. (2018) https://doi.org/10.1016/j.jik.2017.12.003

10. L. S. Zorzo, C. A. Diehl, J. C. Venturini, E. P. Zambon, RAI Mag. O. Adm. A. Inn., 14, 235-249 (2017) https://doi.org/10.1016/j.rai.2017.03.011

11. D. Radushinsky, A. Mottaeva, L. Andreeva, G. Dyakova, IOP Conf. Series: Earth and Environmental Science 90, 012137 (2017) doi :10.1088/17551315/90/1/012218

12. P. Drucker, Management encyclopedia (Vil'yams, 2004)

13. T. Tereshkina, A. Mottaeva, L. Andreeva, T. Larinina, IOP Conf. Series: Earth and Environmental Science, 90, 012138 (2017) doi:10.1088/1755$1315 / 90 / 1 / 012138$

14. A. Mottaeva, E. Vasilyeva, MATEC Web of Conferences, 239, 04019 (2018) doi.org/10.1051/matecconf/201823904019

15. H. Liao, Y.-F. Du, Zh. Huang, Y.-M. Wei Appl. Ener., 179, 479-487 (2016) https://doi.org/10.1016/j.apenergy.2016.06.115

16. E. Akhmetshin, V. Vasyaycheva, Proceedings of the 31st International Business Information Management Association Conference, IBIMA 2018: Innovation Management and Education Excellence through Vision 2020, 3914-3923 (2018)

17. V. P. Chichkanov, E. V. Chistova., A. N. Tyrsin, Econ. A. Soc. Chang.: F, Tr., Forec., 11, 87-102 (2018) https://doi.org/10.15838/esc.2018.5.59.6 